\title{
PENGARUH KOMPETENSI EKSEKUTIF, UKURAN PERUSAHAAN, KOMISARIS INDEPENDEN, DAN KEPEMILIKAN INSTITUSIONAL TERHADAP TAX AVOIDANCE
}

\author{
Dy Retta Merslythalia ${ }^{1}$ \\ Mienati Somya Lasmana ${ }^{2}$ \\ ${ }^{1,2}$ Fakultas Ekonomi dan Bisnis, Universitas Airlangga, Jawa Timur, Indonesia \\ email:msl_feunair@yahoo.com
}

\begin{abstract}
ABSTRAK
Tujuan penelitian ini adalah menguji pengaruh kompetensi eksekutif, ukuran perusahaan, komisaris independen, dan kepemilikan institusional terhadap tax avoidance. Populasi dalam penelitian ini adalah perusahaan manufaktur yang terdaftar di Bursa Efek Indonesia selama tahun 2012 hingga 2014 dengan jumlah 141 perusahaan. Penentuan sampel yang dipilih dalam penelitian menggunakan metode purposive sampling. Pengujian pengaruh kompetensi eksekutif, ukuran perusahaan, komisaris independen, dan kepemilikan institusional terhadap tindakan tax avoidance. Analisis penelitian menggunakan uji regresi linier berganda dengan bantuan software SPSS 20.0. Hasil penelitian menunjukkan terdapat 49 perusahaan yang memenuhi target populasi yang ditetapkan dalam penelitian. Berdasarkan hasil uji analisis linier berganda dengan tingkat signifikansi 5,5\% maka hasil penelitian ini menyimpulkan bahwa: (1) kompetensi eksekutif tidak berpengaruh terhadap tax avoidance (2) ukuran perusahaan tidak berpengaruh terhadap tax avoidance (3) komisaris independen tidak berpengaruh terhadap tax avoidance (4) kepemilikan institusional berpengaruh terhadap tax avoidance.
\end{abstract}

Kata kunci: Kompetensi eksekutif, ukuran perusahaan, komisaris independen, kepemilikan institusional, tax avoidance.

\section{THE EFFECT OF EXECUTIVE COMPETENCY, THE FIRM SIZE, THE INDEPENDENT COMMISIONER AND THE INSTITUSIONAL OWNERSHIP TOWARDS TAXAVOIDANCE}

\begin{abstract}
This research aims to examine the effect of executive competency, the firm size, the independent commissioner and the institutional ownership towards tax avoidance. The number of population in this research is 141 manufacturing companies which are listed in Indonesia Stock Exchange during 2012 to2014. This research uses purposive sampling technique. The multiple linear regression analysis is used to analyze the data. There are 49 companies used as the samples of this study. Based on the conducted data analysis on this research, it concludes that:( 1 ) the executive competence has no effects on tax avoidance ( 2 ) the firm size has no effects on tax avoidance ( 3 ) the independent commissioner has no effects on tax avoidance while (4)the institutional ownership affects tax avoidance .
\end{abstract}

Keywords: Executive competence, firm size, independent commissioner, institutional ownership, tax avoidance DOI: https://doi.org/10.24843/JIAB.2016.v11.i02.p07

\section{PENDAHULUAN}

Kesadaran dan peran aktif masyarakat pembayar pajak sangat diperlukan dalam pemungutan pajak. Pungutan pajak mengurangi penghasilan atau kekayaan individu tetapi pungutan ini akan dikembalikan ke masyarakat melalui pengeluaranpengeluaran rutin dan pengeluaran-pengeluaran pembangunan (Suandy, 2011). Namun demikian, tidak jarang terdapat berbagai perlawanan dari masyarakat pembayar pajak terhadap pemungutan pajak. Perlawan pembayaran pajak terjadi karena perbedaan kepentingan antara pemerintah dengan wajib pajak orang pribadi dan wajib pajak badan.

Perusahaan sebagai wajib pajak badan berusaha untuk membayar pajak sekecil mungkin karena dengan membayar pajak berarti mengurangi kemampuan ekonomis perusahaan (Suandy, 2011). Kondisi itulah yang menyebabkan banyak perusahaan berusaha mencari cara untuk meminimalkan pembayaran pajak. Meminimalisasi pembayaran pajak dilakukan dengan berbagai cara, mulai dari yang 
melanggar peraturan perpajakan (tax evasion) sampai dengan yang masih berada dalam peraturan perpajakan (tax avoidance).

Tax avoidance yang dilakukan oleh perusahaan melalui kebijakan pimpinan perusahaan itu sendiri dalam pengambilan keputusan. Keputusan dan kebijakan diambil tidak semata-mata menggunakan perasaan tetapi juga berdasarkan kemampuan dan pengetahuannya. Kemampuan dan pengetahuannya dapat dilihat berdasarkan pengalamannya. Tentunya keputusan dan kebijakan yang diambil harus selaras dan sejalan dengan tujuan yang ingin dicapai oleh perusahaan.

Tax avoidance yang dilakukan manajemen perusahaan memicu timbulnya konflik agency. Agency theory memandang perbedaan kepentingan antara pemegang saham dengan manajer. Pemegang saham dan manajer berusaha memaksimalkan atau mengoptimalkan kepentingannya. Salah satu mekanisme untuk mengontrol agency theory yaitu menerapkan tata kelola yang baik (good corporate governance). Struktur tata kelola perusahaan (corporate governance) dalam suatu perusahaan bertujuan agar terciptanya suatu tata kelola perusahan yang baik, efektif dan efisien. Dalam mekanisme corporate governance telah diatur halhal yang harus dilakukan oleh perusahaan agar perusahaan dapat terus berkembang namun tidak melanggar aturan pemerintah dan tetap patuh membayar pajak.

Komisaris independen merupakan bagian dari dewan komisaris, yang merupakan organ perusahaan yang memainkan peranan penting dalam pelaksanaan Good Corporate Governance (GCG) secara efektif. Komisaris bertanggung jawab melaksanakan fungsi pengawasan (KNKG, 2006). Dengan adanya fungsi pengawasan maka manajemen tidak bisa semena-mena melakukan tindakan yang dapat menguntungkan dirinya sendiri atau tindakan yang tidak diketahui oleh pemegang saham. Dalam penelitian Winata (2014) prosentase dewan komisaris independen berpengaruh signifikan terhadap tax avoidance. Sedangkan Pranata, Mashudi dkk., (2014) mengatakan sebaliknya, bahwa komisaris independen tidak berpengaruh terhadap tax avoidance.

Faktor lain yang mempengaruhi GCG adalah kepemilikan institusional. Kepemilikan institusional mempunyai peran penting dalam memantau, mendisiplinkan, dan mempengaruhi perilaku manajer. Faisal (2004) menjelaskan kepemilikan institusional merupakan pihak yang memonitor perusahaan dengan kepemilikan institusi yang besar (lebih dari 5\%) mengidentifikasikan kemampuannya untuk memonitor manajemen lebih besar. Adanya kepemilikan institusional di suatu perusahaan mendorong peningkatan pengawasan yang lebih optimal terhadap kinerja manajemen. Pihak institusional yang menguasai saham lebih besar daripada pemegang saham lainnya dapat melakukan pengawasan terhadap kebijakan manajemen yang lebih besar juga sehingga manajemen dapat menghindari perilaku yang merugikan para pemegang saham.

Ukuran perusahaan menggambarkan besar kecilnya suatu perusahaan yang ditunjukkan oleh total aktiva, jumlah penjualan, rata-rata total penjualan dan rata-rata total aktiva (Tiara, 2012). Semakin besar ukuran perusahaannya, maka transaksi yang dilakukan semakin kompleks, sehingga memungkinkan perusahaan untuk memanfaatkan celah-celah atau kelemahan yang ada pada ketentuan perundang-undangan untuk melakukan tindakan tax avoidance dari setiap transaksi.

Berdasarkan latar belakang yang telah diuraikan, maka rumusan masalah penelitian ini adalah apakah kompetensi eksekutif berpengaruh terhadap tax avoidance pada perusahaan manufaktur yang terdaftar di Bursa Efek Indonesia? apakah ukuran perusahaan berpengaruh terhadap tax avoidance pada perusahaan manufaktur yang terdaftar di Bursa Efek Indonesia? apakah komisaris independen berpengaruh terhadap tax avoidance pada perusahaan manufaktur yang terdaftar di Bursa Efek Indonesia? apakah kepemilikan institusional berpengaruh terhadap tax avoidance pada perusahaan manufaktur yang terdaftar di Bursa Efek Indonesia?

Scoot (2006) menjelaskan bahwa teori keagenan adalah perjanjian kontrak antara agen dan principal. Dalam kontrak terdapat perbedaan kepentingan yang dapat mendorong agen untuk melakukan hal-hal yang tidak sesuai dengan kepentingan pemegang saham. Jensen \& Mekling (1976) mendefinisikan hubungan keagenan sebagai suatu kontrak antara pemilik (principal) dan manajemen (agent) untuk menjalankan beberapa jasa atas kepentingan yang melibatkan pendelegasian beberapa wewenang pembuatan keputusan kepada agent.

Anggapan yang melekat pada teori keagenan adalah terdapat konflik kepentingan antara agent yang biasa disebut manajemen dan principal biasa disebut investor. Jensen \& Mekling (1976) mengemukakan asumsi dalam agency theory bahwa masing-masing individu semata-mata termotivasi oleh kepentinganya sendiri sehingga menimbulkan konflik kepentingan antara principal dan agent. Oleh 
karena itu untuk mengatasi principal agent problem, diperlukan tata kelola perusahaan yang baik atau dikenal dengan istilah Good Corporate Governance agar manajer bertindak sesuai dengan kepentingan pemegang saham.

Teori akuntansi positif menjelaskan faktor-faktor yang mempengaruhi manajemen dalam memilih metode akuntansi yang optimal dan mempunyai tujuan tertentu. Terutama dalam mengelola beban pajak. Menurut teori akuntansi positif, metode akuntansi yang digunakan oleh perusahaan tidak harus sama dengan yang lainnya, namun perusahaan diberi kebebasan untuk memilih salah satu alternatif metode yang tersedia untuk meminimumkan biaya kontrak dan memaksimalkan nilai perusahaan. Dengan adanya kebebasan itulah manajer mempunyai kecenderungan melakukan suatu tindakan yang menurut teori akuntansi positif dinamakan sebagai tindakan oportunis (opportunistic behavior). Jadi, tindakan oportunis adalah suatu tindakan yang dilakukan oleh perusahaan dalam memilih kebijakan atau metode akuntansi menguntungkan dan memaksimumkan kepuasan perusahaan (Scott, 2003). Ada 3 hipotesis teori akuntansi positif menurut (Watts dan Zimmerman, 1990), yaitu hipotesis rencana bonus, hipotesis debt covenant dan hipotesis biaya politik

Haruman (2008) Corporate governance merupakan tata kelola perusahaan yang menjelaskan hubungan antara berbagai partisipan dalam perusahaan yang menentukan arah kinerja perusahaan. Setiap perusahaan harus memastikan bahwa asas Good Corporate Governance diterapkan pada setiap aspek bisnis dan di seluruh jajaran perusahaan untuk mencapai kesinambungan usaha perusahaan dengan memperhatikan para pemangku kepentingan.

Lumbantoruan (2005) menyatakan bahwa manajemen pajak merupakan sarana atau alat yang digunakan untuk memenuhi kewajiban perpajakan dengan benar tetapi jumlah pajak yang dibayar akan ditekan serendah mungkin untuk memperoleh laba dan likuiditas yang diharapkan. Terdapat dua tujuan dari manajemen pajak, yaitu melakukan kewajiban perpajakan dengan benar dan usaha efisiensi untuk mencapai laba dan likuiditas yang seharusnya.

Menurut Suandy (2011) penghindaran pajak atau tax avoidance adalah usaha pengurangan jumlah pajak yang dibayarkan secara legal yang dilakukan dengan cara memanfaatkan ketentuan-ketentuan di bidang perpajakan secara optimal, seperti memanfaatkan pengecualian dan pemotongan yang diperkenankan, memanfaatkan hal-hal yang belum diatur, dan memanfaatkan kelemahan-kelemahan yang ada dalam peraturan perpajakan yang berlaku. Manager (eksekutif) merupakan pengelola perusahaan. Kemajuan suatu perusahaan didasarkan atas kemampuan manager dalam mengelola perusahaan oleh karena itu perusahaan membutuhkan manajer yang cakap. Seorang manajer dikatakan cakap apabila manager tersebut memiliki keahlian yang memadai dalam bidang yang menjadi tanggung jawabnya. Pengalaman juga merupakan salah satu faktor yang berperan dalam menentukan tingkat kecanggihan seorang manager (Isnugrahadi dan Kusuma, 2009). Kecakapan manajerial dalam penelitian ini diproksikan menggunakan kompetensi eksekutif. Sebagai seorang eksekutif memiliki kompetensi yang mempengaruhinya dalam membuat suatu keputusan (Harto, 2014).

$\mathrm{H}_{1}$ : Kompetensi eksekutif berpengaruh terhadap tax avoidance pada perusahaan manufaktur yang terdaftar di Bursa Efek Indonesia.

Ukuran perusahaan adalah suatu skala dimana dapat diklasifikasikan besar atau kecil perusahaan, salah satunya berdasarkan total aset (Bujaki dan Richarson, 1997). Semakin besar total aset mengindikasikan semakin besar pula ukuran perusahaan, dan transaksi pun semakin komplek. Hal tersebut berhubungan dengan teori akuntansi positif yang salah satunya terdapat hipotesis biaya politik. Hipotesis biaya politik mengungkapkan perusahaan yang ukurannya sangat besar lebih dituntut Negara untuk memberikan kontributor yang besar melalui pembayaran pajak. Tetapi disisi lain tidak ada orang yang benar-benar rela untuk membayar pajak. Sehingga menimbulkan adanya praktik untuk mengurangi laba. Perusahaan yang termasuk dalam perusahaan besar cenderung memiliki sumber daya yang lebih besar dibandingkan perusahaan yang memiliki skala lebih kecil untuk melakukan pengelolaan pajak. Sumber daya manusia yang ahli dalam perpajakan diperlukan agar dalam pengelolaan pajak dapat dilakukan dengan maksimal guna menekan beban pajak perusahaan (Nicodeme, 2007 dalam Darmadi 2013).

$\mathrm{H}_{2}$ : Ukuran perusahaan berpengaruh terhadap Tax Avoidance pada perusahaan manufaktur yang terdaftar di Bursa Efek Indonesia

Komisaris independen adalah anggota dewan komisaris yang tidak terafiliasi dengan manajemen, anggota dewan komisaris lainnya, dan pemegang saham pengendali bebas dari hubungan bisnis atau hubungan lainnya yang dapat mempengaruhi 
kemampuannya untuk bertindak independen atau bertindak semata-mata demi keuntungan perusahaan. Peran dewan komisaris dalam suatu perusahaan lebih ditekankan pada fungsi monitoring dari implementasi kebijakan direksi. Peran komisaris ini diharapkan akan meminimalisir permasalahan agensi yang timbul antara dewan direksi dengan pemengan saham. Semakin besar jumlah komisaris independen pada dewan komisaris, maka semakin baik mereka bisa memenuhi peran mereka di dalam mengawasi dan mengontrol tindakan-tindakan para direktur eksekutif (Purwaningtyas, 2011).

$\mathrm{H}_{3}$ : Komisaris independen berpengaruh terhadap tax avoidance pada perusahaan manufaktur yang terdaftar di Bursa Efek Indonesia.

Besar kecilnya konsentrasi kepemilikan institusional maka akan mempengaruhi kebijakan pajak agresif oleh perusahaan, dan semakin kecil kepemilikan institusional akan meningkatkan kebijakan pajak agresif, tetapi semakin besar kepemilikan institusional maka akan semakin mengurangi tindakan kebijakan pajak yang agresif. Pemilik institusional memainkan peran penting dalam memantau, mendisiplinkan dan mempengaruhi manajemen. Seharusnya pemilik institusional berdasarkan besar dan hak suara yang dimiliki, dapat memaksa manajer untuk berfokus pada kinerja ekonomi dan menghindari peluang untuk perilaku mementingkan diri sendiri (Annisa, 2011). Handayani (2007) menyatakan bahwa investor institusional merupakan sophisticated investor yang tidak mudah dibohongi oleh tindakan manajer.

$\mathrm{H}_{4}$ : Kepemilikan institusional berpengaruh terhadap tax avoidance pada perusahaan manufaktur yang terdaftar di Bursa Efek Indonesia.

\section{METODE PENELITIAN}

Berdasarkan pemaparan di atas, maka kerangka penelitian yang dapat disusun dalam penelitian pada gambar 1.

Penelitian ini menggunakan data sekunder berupa data annual report perusahaan manufaktur yang terdaftar di BEI tahun 2012-2014 dan telah diolah oleh program SPSS 20.0. Penelitian ini merupakan studi empiris dalam bentuk pengujian hipotesis. Populasi penelitian ini adalah perusahaan manufaktur yang terdaftar di Bursa Efek Indonesia tahun 2012-2014. Teknik pengambilan sampel adalah purposive sampling.

Usaha pengurangan secara legal yang dilakukan dengan cara memanfaatkan hal-hal yang belum

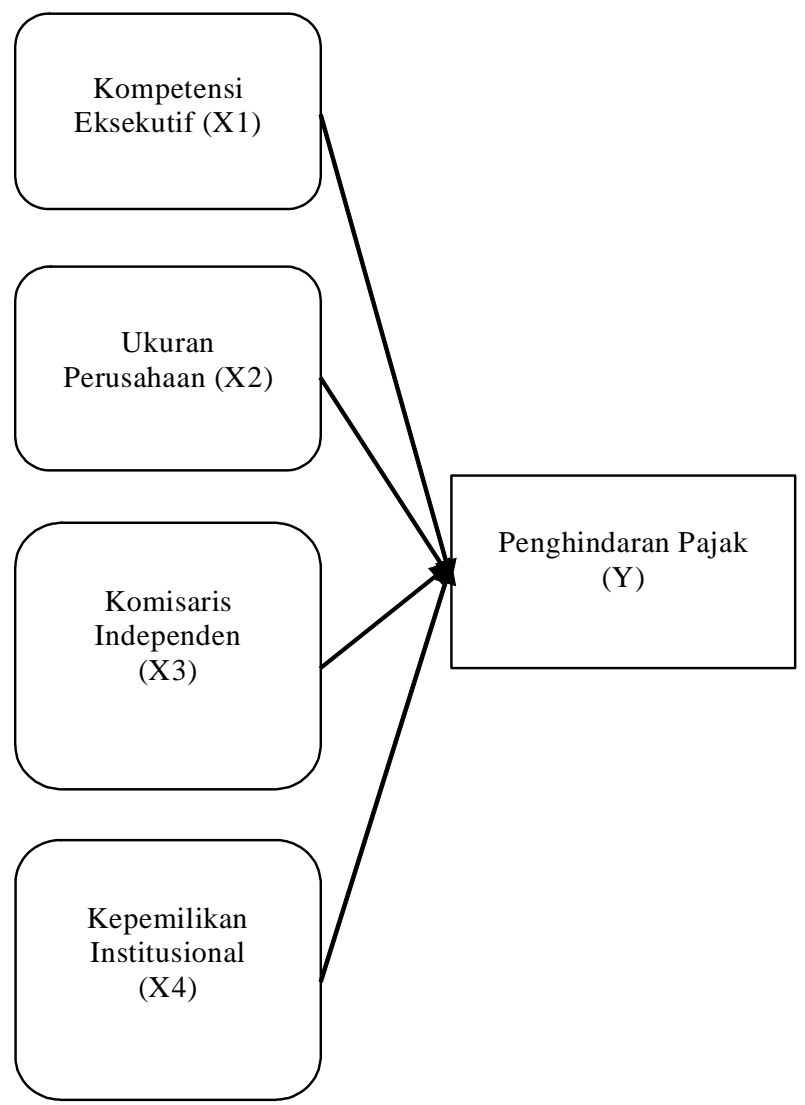

Gambar 1. Model Penelitian

diatur, dan memanfaatkan kelemahan-kelemahan yang ada dalam peraturan perpajakan yang berlaku. Penghindaran pajak dapat diukur dengan berbagai pendekatan salah satunya Current ETR. Dalam penelitian ini menggunakan perhitungan yang telah dilakukan oleh Hanlon dkk. (2010) dengan menggunakan proksi current effective tax rate atau Current ETR.

CurrentETR $=\frac{\text { PajakKini }}{\text { TotalLabaSebelumPajak }}$

Kompetensi eksekutif pada penelitian ini diukur pdengan pengukuran Wolfe dan Hermanson (2004). Indikasi pengukuran menggunakan, 1) Apakah manajer pernah kerja di Kantor Akuntan Publik. 2) Apakah manajer pernah menjadi komite audit. 3) Apakah manajer pernah menjabat sebagai CFO.

Menurut Rego (2003), semakin besar ukuran perusahaannya, maka transaksi yang dilakukan semakin kompleks. Jadi hal itu memungkinkan perusahaan untuk memanfaatkan celah-celah yang ada untuk melakukan tindakan tax avoidance dari setiap transaksi.

Dalam penelitian ini ukuran perusahaan diukur dengan:

SIZE $=$ Log $($ Total Aset $)$ 
Dewan Komisaris terdiri dari pihak yang tidak berasal dari pihak yang terafiliasi dengan manajemen dan kepemilikan saham yang dikenal dengan Komisaris Independen dan Komisaris yang terafiliasi. Dalam penelitian ini komisaris independen diukur sesuai dengan penelitian yang telah dilakukan oleh Dewi dan Jati (2014) sebagai berikut.

$K O M_{-} I N D=\frac{\Sigma \text { Komisaris Independen }}{\Sigma \text { Dewan Komisaris }}$

Menurut Khurana dan Moser (2009) dalam Annisa (2012) besar kecilnya kepemilikan institusional maka mempengaruhi kebijakan agresif yang dilakukan oleh perusahanaan. Dalam penelitian ini kepemilikan institusional diukur menggunakan jumlah proporsi total kepemilikan saham yang $\leq 20 \%$ atau biasa dikenal dengan kepemilikan saham non pengendali (Kieso et .al., 2011).

Berdasarkan hubungan antara variabel maka alat yang digunakan untuk memecahkan dan menganalisis permasalahan adalah regresi linier berganda, dengan persamaan sebagai berikut:

$\mathrm{Y}=\mathrm{a}+\beta_{1} \mathrm{X}_{1}+\beta_{2} \mathrm{X}_{2}+\beta_{3} \mathrm{X}_{3}+\beta_{4} \mathrm{X}_{4}+\varepsilon$

Keterangan :

$\mathrm{Y}=$ Penghindaran pajak

a $\quad$ Konstanta

$\beta_{1}, \beta_{2} . .=$ Koefisien regresi

$\mathrm{X}_{1} \quad$ = Variabel kompetensi eksekutif

$\mathrm{X}_{2}=$ Variabel ukuran perusahaan

$\mathrm{X}_{3}=$ Variabel komisaris independen

$\mathrm{X}_{4} \quad=$ Variabel kepemilikan institusional

$\varepsilon \quad=$ error

\section{HASIL DAN PEMBAHASAN}

Statistik deskriptif digunakan untuk memberikan gambaran dan informasi tentang data variabelvariabel penelitian yang meliputi jumlah sampel, nilai minimum, nilai maksimum, nilai rata-rata, dan deviasi standar. Hasil analisis statistik deskriptif pada penelitian ini disajikan pada Tabel 1 .

Tabel 1.

Statistik Deskriptif

\begin{tabular}{lcrrrr}
\hline & $\mathrm{N}$ & \multicolumn{1}{c}{ Min. } & \multicolumn{1}{c}{ Max. } & \multicolumn{1}{c}{ Mean } & \multicolumn{1}{c}{ Std. Dev. } \\
\hline Curetr & 147 & 0,043 & 4,55 & 0,302 & 0,375 \\
Kompetensi & 147 & 0 & 2 & 0,610 & 0,754 \\
Size & 147 & 10,977 & 14,373 & 12,323 & 0,780 \\
Kom_Ind & 147 & 0,200 & 1,000 & 0,394 & 0,128 \\
Ins_Own & 147 & 0,000 & 81,000 & 12,316 & 19,169 \\
Valid N (Listwise) & 147 & & & & \\
\hline
\end{tabular}

Sumber: Data diolah, 2016

Berdasarkan Tabel 1 variabel-variabel penelitian yang dijelaskan dalam uji statistik deskriptif. Variabel tax avoidance diproksikan dengan current effective tax rate (CurETR). Hasil analisis statistik deskriptif menunjukkan CurETR memiliki nilai minimum sebesar 0,043 dan nilai maksimum sebesar 4,552. Rata-rata CUrETR sebesar 0,302 dan deviasi standar sebesar 0,375 dimana nilai deviasi standar lebih besar dari nilai rata-ratanya. Hal ini menunjukkan adanya fluktuasi tarif pajak yang dibayar oleh perusahaan manufaktur yang menjadi sampel.

Variabel kompetensi diproksikan dengan pengalaman kerja eksekutif di KAP, internal auditor, dan CFO . Hasil analisis statistik deskriptif menunjukkan kompetensi memiliki nilai minimum sebesar 0,000 dan nilai maksimum sebesar 2. Nilai rata-rata kompetensi sebesar 0,610 dan deviasi standar sebesar 0,754, dimana nilai deviasi standar lebih besar dari nilai rata-ratanya. Hal ini menunjukkan adanya variatif kompetensi eksekutif (mempunyai pengalaman kerja di KAP dan internal auditor) yang bekerja di perusahaan manufaktur yang menjadi sampel.

Variabel ukuran perusahaan diproksikan dengan $\log$ asset perusahaan sampel. Hasil analisis statistik deskriptif menunjukkan log asset perusahaan memiliki nilai minimum sebesar 10,977 dan nilai maksimum sebesar 14,373. Nlai Rata-rata log asset perusahaan sebesar 12,323 dan deviasi standar sebesar 0,780, dimana nilai deviasi standar lebih kecil dari nilai rata-ratanya. Hal ini menunjukkan tidak adanya fluktuasi ukuran perusahaan manufaktur yang menjadi sampel.

Variabel komisaris independen diproksikan dengan jumlah keberadaan komisaris independen dibanding jumlah komisaris pada perusahaan sampel. Hasil analisis statistik deskriptif variable komisaris independen memiliki nilai minimum sebesar 0,200 dan nilai maksimum sebesar 1,000. Nilai Rata-rata komisaris independen sebesar 0,394 dan deviasi 
standar sebesar 0,128. Nilai deviasi standar lebih kecil dari nilai rata-ratanya. Hal ini menunjukkan rata-rata perusahaan memiliki komisaris independen pada perusahaan manufaktur yang menjadi sampel.

Variabel kepemilikan institusi yang diproksikan dengan jumlah proporsi total kepemilikan saham $\leq 20 \%$ pada perusahaan sampel. Hasil analisis statistik deskriptif variable kepemilikan institusi memiliki nilai minimum sebesar 0,000 dan nilai maksimum sebesar
81,000. Nilai Rata-rata komisaris independen sebesar 12,316 dan deviasi standar sebesar 19,169. Nilai deviasi standar lebih besar dari nilai rata-ratanya. Hal ini menunjukkan perusahaan variasi yang besar perusahaan kepemilikan institusi pada perusahaan manufaktur yang menjadi sampel.

Berdasarkan perhitungan dengan bantuan program SPSS, maka hasil analisis regresi linear berganda disajikan pada Tabel 2 .

Tabel 2.

Hasil Analisis Linier Berganda

\begin{tabular}{|c|c|c|c|c|c|}
\hline \multirow[t]{2}{*}{ Model } & \multicolumn{2}{|c|}{$\begin{array}{l}\text { Unstandardized } \\
\text { Coefficients }\end{array}$} & \multirow{2}{*}{$\begin{array}{c}\text { Standardized } \\
\text { Coefficients } \\
\text { Beta } \\
\end{array}$} & \multirow[t]{2}{*}{$\mathrm{t}$} & \multirow[t]{2}{*}{ Sig. } \\
\hline & $\mathrm{B}$ & Std. Error & & & \\
\hline (Constant) & 0,196 & 0,094 & & 2,087 & 0,039 \\
\hline KOMPETENSI & 0,006 & 0,007 & 0,084 & 0,824 & 0,412 \\
\hline 1 SIZE & 0,002 & 0,008 & 0,023 & 0,218 & 0,828 \\
\hline KOM_IND & 0,027 & 0,037 & 0,066 & 0,726 & 0,469 \\
\hline INS_OWN & 0,001 & 0,000 & 0,281 & 3,048 & 0,003 \\
\hline
\end{tabular}

Sumber: Data diolah,2016

Berdasarkan Tabel 2, maka dapat disusun suatu persamaan regresi linier berganda sebagai berikut: CurrETR $=0,196+0,006$ KOMPETENSI $+0,002$ SIZE + 0,027 KOM_IND + 0,001 INS_OWN $+\varepsilon$

Nilai konstanta sebesar 0,196. Hal ini menunjukkan bahwa jika variabel kompetensi eksekutif $\left(\mathrm{X}_{1}\right)$, ukuran perusahaan $\left(\mathrm{X}_{2}\right)$, komisaris independen $\left(\mathrm{X}_{3}\right)$ dan kepemilikan institusional $\left(\mathrm{X}_{4}\right)$ tidak mengalami perubahan.

Nilai koefisien regresi $\left(\beta_{1}\right)$ untuk variabel KOMPETENSI $\left(\mathrm{X}_{1}\right)$ sebesar 0,006 , hal ini menunjukkan jika jumlah kompetensi eksekutif meningkat satu satuan, maka nilai CurETR akan mengalami kenaikan sebesar 0,006 kali dan berdampak terhadap penurunan tax avoidance.

Nilai koefisien regresi $\left(\beta_{2}\right)$ untuk variabel SIZE sebesar 0,002, hal ini menunjukkan jika ukuran perusahaan mengalami kenaikan satu kali, maka nilai CurETR akan mengalami kenaikan sebesar 0,002 kali dan berdampak pada penurunan tax avoidance.

Nilai koefisien regresi $\left(\beta_{3}\right)$ untuk variabel KOM_IND sebesar 0,27, hal ini menunjukkan jika proporsi komisaris independen mengalami perubahan satu kali, maka nilai CurETR akan mengalami kenaikan sebesar 0,27 kali dan berdampak pada penurunan tax avoidance.

Nilai koefisien regresi $\left(\beta_{4}\right)$ untuk variabel INS_OWN sebesar 0,001 hal ini menunjukkan jika proporsi kepemilikan institusional mengalami perubahan satu kali, maka nilai CurETR akan mengalami kenaikan sebesar 0,001 kali dan berdampak pada penurunan tax avoidance.

Koefisien determinasi $\left(\mathrm{R}^{2}\right)$ digunakan untuk mengukur seberapa jauh kemampuan model dalam menerangkan variasi variabel dependen dapat dilihat pada Tabel 3.

Berdasarkan tabel 3 diperoleh nilai adjusted $R$ Square $\left(\mathrm{R}^{2}\right)$ sebesar 0,055 . Hal ini menunjukkan bahwa persentase pengaruh variabel bebas (kompetensi eksekutif, ukuran perusahaan, komisaris independen dan kepemilikan institusional) terhadap variabel terikat (tax avoidance) adalah hanya sebesar 5,5\%.

Hipotesis pertama $\left(\mathrm{H}_{1}\right)$ menyatakan bahwa kompetensi eksekutif berpengaruh terhadap tax avoidance. Berdasarkan hasil analisis dalam penelitian

Tabel 3.

Koefisien Determinasi

\begin{tabular}{llrrrr}
\hline Model & R & R Square & \multicolumn{1}{c}{$\begin{array}{c}\text { Adjusted R } \\
\text { Square }\end{array}$} & $\begin{array}{c}\text { Std. Error of the } \\
\text { Estimate }\end{array}$ & Durbin-Watson \\
\hline 1 & $0,295^{\mathrm{a}}$ & 0,087 & 0,055 & 0,055 & 1,257 \\
\hline
\end{tabular}

Sumber: Data diolah, 2016 
ini, kompetensi eksekutif tidak berpengaruh terhadap tax avoidance. Seorang direktur atau direktur utama perusahaan memiliki peranan penting dalam pengambilan keputusan yang sesuai dengan tujuan dan kebijakan perusahaan. Dalam pengambilan keputusan tentu setiap individu memiliki kemampuan dan pengetahuan yang berbeda-beda. Hasil penelitian ini menunjukkan jumlah direksi dengan kompetensi yang telah ditetapkan tidak berpengaruh terhadap tindakan tax avoidance yang dilakukan oleh perusahaan.

Direksi dengan kompetensi yang tinggi berupaya untuk memberikan laporan keuangan yang relevan dan akuntabel sebagai acuan untuk memperbaiki kinerja manajemen di masa depan. Penyajian laporan keuangan secara baik dengan menghindari tindakantindakan kecurangan seperti melakukan tindakan tax avoidance dapat meningkatkan kepercayaan publik mengenai pengelolaan perusahaan secara baik dalam memenuhi kewajiban perpajakan yang dikenakan oleh Negara terhadap perusahaan. Dengan demikian hipotesis 1 (satu) yang menyatakan bahwa kompetensi eksekutif berpengaruh terhadap tax avoidance tidak terbukti.

Hipotesis dua $\left(\mathrm{H}_{2}\right)$ menyatakan bahwa ukuran perusahaan berpengaruh terhadap tax avoidance. Berdasarkan hasil analisis dalam penelitian ini, ukuran perusahaan tidak berpengaruh terhadap tax avoidance. Perusahaan besar tentu menarik perhatian besar dari pemerintah terkait dengan laba yang diperoleh, sehingga dia dapat menarik perhatian fiskus untuk memeriksa atau dikenakan pajak yang sesuai dengan peraturan yang berlaku. Maka dari itu, perusahaan tidak mau mengambil resiko untuk direpotkan adanya proses pemeriksaan ataupun dikenakan sanksi lain yang dapat menyebabkan dampak buruk bagi citra perusahaan dalam jangka panjang. Maka dari itu besar atau kecil perusahaan sama-sama patuh terhadap peraturan perpajakan. Dengan demikian hipotesis 2 (dua) yang menyatakan bahwa ukuran perusahaan berpengaruh terhadap tax avoidance tidak terbukti.

Hipotesis tiga $\left(\mathrm{H}_{3}\right)$ menyatakan bahwa komisaris independen berpengaruh terhadap tax avoidance. Berdasarkan hasil penelitian, komisaris independen tidak berpengaruh signifikan terhadap tax avoidance. Komisaris independen tidak berpengaruh signifikan terhadap penghindaran pajak. Hal ini dikarenakan banyak atau sedikitnya proporsi komisaris independen di suatu perusahaan tidak menjamin bahwa komisaris independen dapat menghindari tindakan tax avoidance. Tidak adanya pengaruh komisaris independen terhadap tax avoidance menandakan bahwa keberadaan dewan komisaris independen tidak efektif dalam usaha pencegahan tindakan tax avoidance.

Penambahan anggota komisaris independen pada perusahaan mungkin hanya untuk memenuhi ketentuan yang ditetapkan, sementara pemegang saham mayoritas masih memegang peranan penting sehingga kinerja dewan komisaris tidak meningkat. Dengan demikian hipotesis tiga yang menyatakan bahwa komisaris independen berpengaruh terhadap tax avoidance tidak terbukti.

Hipotesis empat $\left(\mathrm{H}_{4}\right)$ menyatakan bahwa kepemilikan institusional berpengaruh terhadap tax avoidance. Berdasarkan hasil penelitian, kepemilikan institusional berpengaruh negatif terhadap tax avoidance. Kepemilikan institusional berpengaruh terhadap tax avoidance. Hal ini dapat disebabkan baik besar atau kecil persentase kepemilikan saham dapat mampengaruhi kebijakan yang diambil.

Kepemilikan institusional memainkan peran penting dalam memantau, mendisiplinkan dan mempengaruhi keputusan manajemen. Hal ini juga dibuktikan bahwa semakin besar kepemilikan saham oleh investor maka semakin kuat investor untuk mendesak manajer untuk bertindak sesuai dengan tujuan investor dan tidak mementingkan dirinya sendiri. Dengan demikian hipotesis empat yang menyatakan bahwa kepemilikan institusional berpengaruh terhadap tax avoidance terbukti.

\section{SIMPULAN}

Berdasarkan hasil analisis menggunakan 147 sampel terdiri atas 49 perusahaan manufaktur yang terdaftar di Bursa Efek Indonesia tahun 2012-2014, dapat disimpulkan kompetensi eksekutif tidak berpengaruh terhadap tax avoidance. Ukuran perusahaan tidak berpengaruh signifikan terhadap tax avoidance. Komisaris independen tidak berpengaruh signifikan terhadap tax avoidance. Kepemilikan institusional berpengaruh negatif terhadap tax avoidance.

Saran yang diberikan peneliti adalah variabel kompetensi eksekutif tidak hanya diukur dengan menggunakan tiga kriteria yang dijelaskan sebelumnya. Kompetensi eksekutif bisa diukur berdasarkan kualifikasi keahlian dan pengalaman dalam bidang akuntansi, dengan melihat pendidikan format eksekutif dan pelatihan-pelatihan atau seminar yang diikuti oleh eksekutif bidang perpajakan. Komisaris independen merupakan bagian dari GCG yang mana bisa diganti dengan proksi lain dari bentuk GCG eksternal seperti komite audit. Selain itu untuk 
penelitian selanjutnya bisa menggunakan jangka waktu lebih panjang sehingga upaya tax avoidance disuatu perusahaan bisa lebih terlihat.

\section{REFERENSI}

Annisa, Nuralifmida Ayu, \& Lulus Kurniasih. (2012). Pengaruh Corporate Governance Terhadap Tax Avoidance. Jurnal Akuntansi Dan Auditing, 8(2), 95-189.

Dewi, Ni Nyoman Kristiana, \& I Ketut Jati. (2014). Pengaruh Karakter Eksekutif, Karakteristik Perusahaan, dan Dimensi Tata Kelola Perusahaan yang Baik ada Tax Avoidance di Bursa Efek Indonesia. E-Jurnal Akuntansi Universitas Udayana, 6, 249-260.

Faisal, Abdullah. (2004). Dasar-dasar Manajemen Keuangan.Malang:UniversitasMuhammadiyah.

Ghozali, I. (2011). Analisis Multivariate Program IBM SPSS 19. Semarang: Badan Penerbit Universitas Diponogoro.

Harto, U. H. P. (2014). Analisis Pengaruh Kompensasi Eksekutif, Kepemilikan Saham Eksekutif dan Preferensi Risiko Eksekutif terhadap Penghindaran Pajak Perusahaan. Diponegoro Journal of Accounting (3)2, 110.

Haruman, Tendi. (2008). Struktur Kepemilikan, Keputusan Keuangan dan Nilai Perusahaan. Finance and Banking Journal. 10(2), 150165.

Jensen, M. C., \& William H. Meckling. (1976). Theory of The Firm: Managerial Behavior, Agency Cost and Ownership Structure. Journal of Financial Economics, 3, 305-360.

Kieso, Weygandt, \& Warfield. (2011). Akuntansi Intermediate, Jakarta: Edisi Kedua Belas, Erlangga,

Komite Nasional Kebijakan Governance. (2006). Pedoman Umum Good Corporate Governance Indonesia. Jakarta.

Lumbantoruan, Sophar. (2005). Akuntansi Pajak. Jakarta : PT Gramedia Widiasarana Indonesia
Pranata, F. Mashudi, Puspa, D. F., \& Herawati. (2014). Pengaruh karakter Eksekutif dan Corporate Governance terhadap Tax Avoidamce. Padang: Universitas Bung Hatta.

Purwaningtyas, Frysa Praditha. (2011). Analisis Pengaruh Mekanisme Good Corporate Governance terhadap Nilai Perusahaan (Studi Empiris pada Perusahaan Manufaktur yang Terdaftar di BEI Tahun 2007-2009). Skripsi. Program Sarjana Fakultas Ekonomika dan Bisnis Universitas Diponegoro.

Scott, William R. (2003). Financial Accounting Theory, Third Edition, University of Waterloo.

Scoot, William R. (200)6. Financial Accounting Theory. Edisi Keenam. United States of Americas:Pearson Pentice Hall.

Suandy, Early. (2011a). Hukum Pajak. Edisi Kelima. Jakarta: Salemba Empat.

Sugiyono. (2014). Metode Penelitian Pendidikan: Bandung: Alfabeta

Tiara, Hana. (2012). Pengaruh Ukuran Perusahaan dan Profitabilitas terhadap Struktur Modal Pada Perusahaan Whole Sale and Retail Trade yang Terdaftar di Bursa Efek Indonesia Periode 20082010. E-journal.

Undang-Undang Republik Indonesia Nomor 28 Tahun 2007 Tentang Perubahan Ketiga Atas Undang-Undang Nomor 6 Tahun 1983 Tentang Ketentuan Umum dan Tata Cara Perpajakan.

_-_- (2011b). Perencanaan Pajak. Edisi Kelima. Jakarta: Salemba Empat.

Watts, Ross L., \& Jerold. L. Zimmerman. (1990). Positive Accounting Theory: A ten Year perspective. The Accounting Review. Journal, 65(1),131-156.

Wolfe, David T., \& R. Hermanson. (2004). The fraud diamond: Considering the four elements of fraud. The CPA Journal, 38-42. 